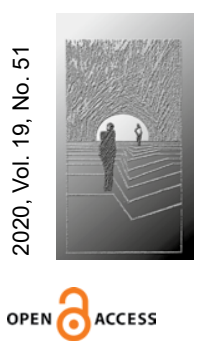

Aleksandra Witoszek-Kubicka

http://orcid.org/0000-0001-5304-3379

Cracow University of Economics

aleksandra.witoszek@uek.krakow.pl

DOI: $10.35765 / h w .1897$

\title{
The Use of Game Elements in Higher Education in the Context of Motivating Different Types of Users of Gamified Systems ${ }^{1}$
}

\begin{abstract}
RESEARCH OBJECTIVE: The main purpose of the article is to select the elements of games that increase the student's external and internal motivation tailored to the specific type of player he/she represents.
\end{abstract}

THE RESEARCH PROBLEM AND METHODS: The research problem is the issue of motivating students using gamification. The author addresses the issue of preparation of classes that will actually translate into motivation to learn practical skills, but also to develop, pose difficult questions and engage in the learning process. The research is based on the Self-Determination Theory and Marczewski gamification users typology. The basic method used in the presented research is an analysis of a questionnaire conducted among students of the Cracow University of Economics.

THE PROCESS OF ARGUMENTATION: The article consists of two main parts. The first presents the concept of gamification and its use in motivating. Second part of the article is divided into three subsections. First of them contains characteristics of different participants types in gamification projects. Second of them presents assumption and research hypotheses, the other one includes analysis of the results and conclusions of the study.

RESEARCH RESULTS: Thanks to the conducted research and based on the subject literature, the predispositions of students to accept the use of selected mechanisms known from games were determined. The conducted research confirmed the assumed hypothesis that the legitimacy of using particular elements of gamification depends on the target group of participants. However, the hypothesis of ineffectiveness of the use of elements specific to the type of player was not confirmed.

CONCLUSIONS, INNOVATIONS, AND RECOMMENDATIONS: Further research is needed to verify this assumption, e.g. using a gamification project. Due to the limited research sample, the results do not reflect the entire population, but provide a basis for further research on the motivational elements of individual participants in gamification systems. They can also be

${ }^{1}$ Publication was financed from the funds granted to the Cracow University of Economics, $120 /$ ZZZ/2020/PRO. 


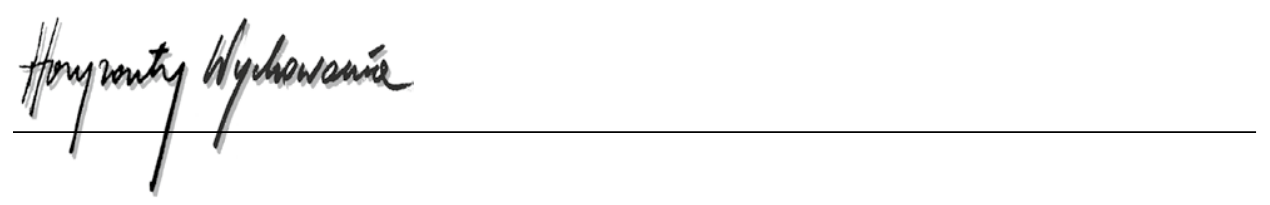

treated as a guideline for the implementation of gamification in the curricula addressed to students in Poland.

\section{$\rightarrow$ KEYWORDS: GAMIFICATION, GAMIFICATION USER TYPES, SELF-DETERMINATION THEORY}

\section{Introduction}

Today's students have grown up with digital technologies and have new approaches and often higher demands on the teaching and learning process. For this reason, academic teachers face new challenges to adapt their classes to students' needs in order to motivate them not only to learn practical skills, but also to develop, pose difficult questions and engage in the learning process. Gamification, i.e. the use of game mechanisms in a non-game-related context, is indicated as one of the ways to build such motivation. Expert analyses show the promising results of building commitment and motivating peoples and students using it but also indicate that there is little recognition of the tool in Poland, stressing in particular the need to match the appropriate elements of gamification to the preferences of participants (Kozłowska, 2016, pp. 38-40; Swacha, 2015, p. 180). The aim of the article is to select the elements of games that increase the student's external and internal motivation tailored to the specific type of player he/she represents. On the basis of the subject literature and surveys carried out, elements of games necessary for implementation in the gamification system dedicated to the Cracow University of Economics students were distinguished.

\section{The use of gamification in motivating in the light of Self-Determination Theory}

Gamification is the use of game elements in tasks that are performed in real life to influence people's behaviour (Werbach, 2012, p. 72). This means that such areas of life and business practice as: human resources management, marketing, sales, project management, sport or education are enriched with elements from games. The aim of implementing gamification is to increase people's motivation to perform given activities, increase their involvement and facilitate problem solving (Zicherman \& Cunningham, 2011, p. 14).

The elements and process of designing gamification solutions are based on the MDA (Mechanics - Dynamics - Aesthetics) game design system. This system consists of three basic elements (Zicherman \& Cunningham, 2011, pp. 35-36): game mechanics, game dynamics and game aesthetics. The whole construction is based on elements which are supposed to create a certain dynamics of the game and evoke emotions motivating the player to continue playing. With regard to building a gamification system, the designers' task is to select mechanisms that will translate into the desired dynamics and 
evoke specific emotions in employees, students, customers or other rivalry groups. The essence of gameplay, like games, is to motivate people to perform specific activities.

Research indicates that gamification can be one way to motivate students to learn, and the use of game elements not only increases efficiency but also the pleasure of learning (Sahin \& Namli, 2016, p. 41) (Da Rocha Seixas, Gomes, \& De Melo Filho, 2016, p. 59).

However, there are also uncertainties about the use of game elements in an unrelated context. One of them is the replacement of a mutually beneficial relationship (e.g. pay for work) with a relationship in which only one party, usually the employer, obtains benefits and the other - in this context, the employee makes an effort, receiving in return only apparent, virtual rewards, devoid of real value, referred to as exploitationware (Bogost, 2013). However, it is pointed out that this problem does not occur in education, where the goal of both sides - teacher and student - is effective learning (Swacha, 2015, p. 180). A wave of criticism of the use of solutions based on game elements in education is caused by the fact that gamification is reduced to so-called scoring, i.e. the introduction of points and rankings as the only game elements (Zainuddin et al., 2020). Playing in this way often leads to an increase in unhealthy competition and even aggression between users. When designing games, developers can choose the mechanisms depending on the assumed target group or direct the product to an undefined audience. Unlike games, in the case of gamification in education, the target group is very well defined and known. Hence, an important part of the gamification model are the so-called players, i.e. participants. The misalignment of mechanisms to users' needs may result in short-term involvement and action based solely on external drivers (Litwin, 2014). It is pointed out that, in particular when implementing gaming elements in education, it is crucial to define students' profiles to determine which elements should be used (Kiryakova, Angelova, \& Yordanova, 2014). This approach is reflected in gamification models, where regardless of the purpose of gamification there is a question of adapting the gamification system to the users, e.g. Gamification Model Canvas consists of such elements as: platform, mechanics, dynamics, aesthetics, behavior, players, components, costs, profits (Jimenez, n.d.). Since gamification is based on inducing motivation to undertake certain activities, in order to bring the gamification activity closer, it is worth noting the very concept of motivation.

Motivation is one of the main issues of positive psychology and at the same time one of the basic management functions (Piotrowska \& Puchała, 2012). This is an issue raised in many practical areas and by academic theorists, but still interesting. It provokes heated discussions mainly due to the vastness of variables to be taken into account when referring to motivation. Its definition is very broad and not fully specified due to the interdisciplinary nature of the concept. The noun "motivation" itself is derived from the Latin words movere which means "move," motus which means "movement" or moveo translated as "setting in motion" (Kacprzak-Bieracka, Skura-Madziała, Kopański, Brukwicka, Lishchynsky, \& Mazurek, 2014, pp. 2-3). Commonly, the motivation is to take some action. 


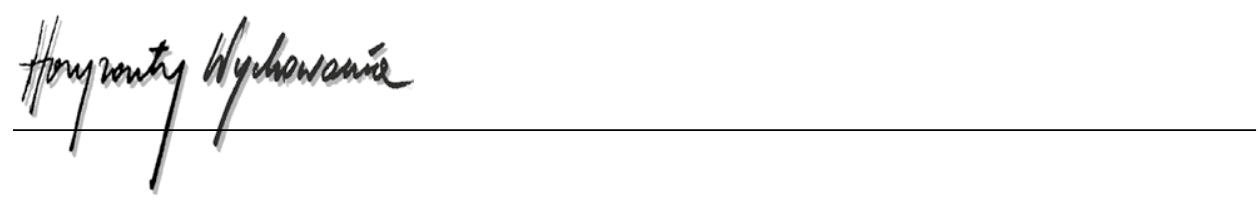

There are many concepts of motivation, among which four main theoretical models can be distinguished (Mielniczuk, Łaguna, Januszewski, \& Artymiak, 2016, pp. 103-105):

- homeostatic, according to which the motivation to act results from the body's imbalance and the desire to restore it,

- excitement, where the source of action is an external stimulus, when it disappears, the motivation also disappears,

- humanistic, according to which the source of behavior is internal needs,

- cognitive, where it is assumed that stimuli do not cause an immediate reaction, but trigger cognitive processes, the source of motivation is processed information.

The group of cognitive motivation concepts includes Self-Determination Theory (SDT). Its authors, R. Ryan and E. Deci, while researching the sources of human activity, they noticed that people differ not only in strength, but also in the type of motivation. The authors have distinguished three types of motivation (Deci, Vallerand, Pelletier, \& Ryan, 1991, pp. 325-346):

- internal,

- external,

- amotivation.

The basis of Self-Determination Theory are three innate needs (Ryan \& Deci, 2000, pp. 68-73):

- competency,

- relatedness,

- autonomy.

The need for competencies includes understanding how to achieve internal or external benefits and efficiency. The need for a relatedness refers to a sense of security and satisfying contact with other people. Autonomy, in turn, is based on the independent initiation of behavior and its internal regulation. In line with the concept of SDT, the ability to satisfy these three needs puts the individual in a state of motivation, and their unsatisfaction leads to amotivation.

The authors of Self-Determination Theory recognize the value of internal motivation, but also point out that a properly regulated external motivation can result in a similar level of commitment to perform an action (Ryan \& Deci, 2000, pp. 68-73). According to the contents of the SDT, the motivation may be conditioned by five different types of regulation(Ryan \& Deci, 2000, pp. 68-73):

- external,

- introjected,

- based on identification,

- integrated,

- internal.

An external regulation refers to actions motivated by a possible external reward or penalty. The place of initiation of behavior is seen as completely external to the person. An introjected regulation is based on rules and requirements adopted by a person, but not integrated with his or her own "self." So it is not accepted as a self-regulatory form. 
Behavior is triggered by possible internal rewards such as complacency, pride, ego fulfillment, or the threat of internal punishment such as guilt. An identification-based regulation refers to a situation in which a person values, identifies oneself with behavior and accepts it. Behavior is more autonomous than that regulated by external stimuli or internal rewards and punishments. Motivation is still external, but the place where it originated is rather seen as internal, because activities have personal meaning and are consciously valued. The most advanced form of external motivation is integrated regulation. The place where motivation originates is perceived by the person as its interior, because the regulatory process is individualized and integrated with values, needs and a coherent sense of self. The internal regulation is based on the interest and pleasure of the activity itself. An action motivated by a fully internal regulation is authentic and consistent with the person's own self. However, as research shows, externally motivated actions can also become self-determined when individuals identify themselves with them and assimilate the regulation completely. Thus, through internalization and integration, externally motivated people can continue to be highly engaged and authentic if their needs for competence, relationships and autonomy are met (Ryan \& Deci, 2000, pp. 68-73).

\section{Types and motivations of participants in the Cracow University of Economics students}

\subsection{Types of participants in gamified systems}

Game designers have been analyzing players' behavior and the influence of the mechanisms used on their motivation for years. In practice, the designers most often refer to the systematics created by R. Bartle. The author conducted observations of behaviors, as well as interviews with users of games at the highest levels, asking about their expectations from the game. On the basis of answers and analysis of behavior, R. Bartle defined their motivation to play the game and defined four types of players: explorer, achiever, socializer, killer, which are affected by different mechanisms used in the game. Explorers are motivated by discovering the game world and the laws that govern it. The achievers are focused on reaching their goals and maximizing their performance in the game. The socializers appreciate the opportunity to cooperate and interact with other players. The killers focus on influencing other users and defeating opponents (Bartle, 1996).

The author developed a test to identify each of these types. It is assumed that the majority of people are socializers (75\%) and the least numerous group are killers (5\%) (Zicherman, Cunningham, 2011, pp. 35-36). R. Bartle also described how different types of players interact with each other and outlined the importance of player types in game design, especially the choice of motivating mechanisms for individual users. Similarly, the developers of gamification, in order to best adapt it to the audience, use R. Bartle's tool to determine the mechanisms best motivating the people for whom the gamification 


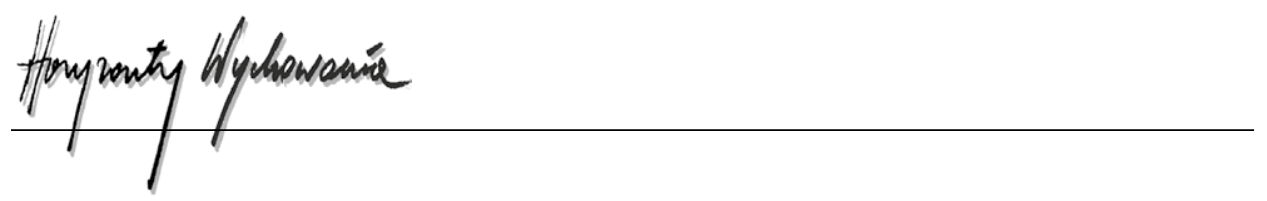

is designed. However, with a deeper understanding of the gamification topic, there are objections to the use of R. Bartle's test and systematics, and their close connection to Massively Multiplayer Online Role-Playing Games (MMORPG) (Zając, 2014). Similar conclusions can be drawn from the analysis of the test. The questions are based on the choice of one of the two alternatives according to the feelings of the subject. The statements refer directly to the preferences for action in multiplayer computer games and may be incomprehensible to those who are not users.

The need to adapt gamification systems to different users has led to research on the types of gamification participants. The effectiveness of custom personalization in the context of gamification projects has been demonstrated (Orji, Nacke, \& Di Marco, 2017). A promising approach to the personalization of gaming applications is shown by research based on the assumption that the motivation to play is based on the characteristics of the person or "player types." Empirical research has shown that defining user personality traits allows to predict the level of acceptance for several commonly used game design elements such as levels, points, scoreboards, avatars, tasks or challenges (Xu, Karanam, \& Voida, 2016). It has also been shown that the player types themselves can be partially correlated with personality traits. Nevertheless, researchers of game users indicate that personality traits are only a partial explanation of the different motivations for playing, which supports the view that specially tailored typologies of players may better serve to personalize gamification projects than general theories of personality, such as the often cited and currently used Big Five model in personality research (Tondello, Wehbe, Diamond, Busch, Marczewski, \& Nacke, 2016, pp. 229-243).

Based on the developed types of players R. Bartle and the Self-Determination Theory, A. Marczewski distinguished four basic types of gamification users: socializer, free spirit, achiever and philanthropist. The motivators of these participants are respectively: relatedness, autonomy, mastery and purpose defined by the creator with the abbreviation RAMP. A. Marczewski also distinguished two additional types: player and disruptor, which cannot be directly related to the aforementioned motivators (Marczewski, 2015).

The socializer is motivated by building relationships with other participants. Develops a social network. A free spirit is motivated by autonomy and the ability to express oneself. It does not want to be limited in the way it uses the system, it discovers its imperfections and builds its own solutions. The achiever strives to master his/her tasks. He/she is motivated by the need to obtain a status attesting to his achievements. The motivation of a philanthropist is based on the feeling that he/she is part of something bigger. He/she is motivated by helping others and a common goal. The player is only interested in the prizes that can win. A beginner user who joins the system motivated by gaining points or levels is often this type of user. For most users, this external motivation develops over time into one of the distinguished internal motivations. The disruptor acts against the system. He/she is aimed at harming other users by manipulating or interfering with the system. One of the subtypes of the disruptoris the improver, which has good intentions. $\mathrm{He} / \mathrm{she}$ is looking for system deficiencies in order to improve the system (Marczewski, 2015). On the basis of the motivation of the different types of participants in the game, 
we can distinguish elements, the use of which has a direct impact on increasing their involvement. The relationships are shown in Table 1. As the research shows, some elements are strongly correlated with several types of users and are therefore included as additional elements in the table. The influence of mechanisms and dynamics assigned to the type of philanthropist requires further research (Tondello, Wehbe, Diamond, Busch, Marczewski, \& Nacke, 2016, pp. 229-243).

Table 1

Game elements and player types

\begin{tabular}{|c|c|c|c|}
\hline User types & \multicolumn{2}{|c|}{ Basic elements } & Additional elements \\
\hline Socializer & $\begin{array}{l}- \\
- \\
- \\
-\end{array}$ & $\begin{array}{l}\text { Guilds or Teams } \\
\text { Social Networks } \\
\text { Social Comparison } \\
\text { Social Competition } \\
\text { Social Discovery }\end{array}$ & \\
\hline Free Spirit & $\begin{array}{l}- \\
- \\
- \\
- \\
- \\
- \\
-\end{array}$ & $\begin{array}{l}\text { Exploratory Tasks } \\
\text { Nonlinear Gameplay } \\
\text { Easter Eggs } \\
\text { Unlockable Content } \\
\text { Learning } \\
\text { Anonymity } \\
\text { Anarchic Gameplay }\end{array}$ & $\begin{array}{ll}- & \text { Customization } \\
- & \text { Challenges } \\
- & \text { Creativity Tools }\end{array}$ \\
\hline Achiever & $\begin{array}{l}- \\
- \\
-\end{array}$ & $\begin{array}{l}\text { Challenges } \\
\text { Certificates } \\
\text { Quests }\end{array}$ & $\begin{array}{ll}- & \text { Anonymity } \\
- & \text { Learning } \\
- & \text { Badges } \\
- & \text { Levels or Progression }\end{array}$ \\
\hline Philantropist & $\begin{array}{l}- \\
- \\
- \\
-\end{array}$ & $\begin{array}{l}\text { Collection and Trading } \\
\text { Gifting } \\
\text { Knowledge Sharing } \\
\text { Administrative Roles }\end{array}$ & \\
\hline Player & $\begin{array}{l}- \\
- \\
- \\
- \\
- \\
- \\
-\end{array}$ & $\begin{array}{l}\text { Points } \\
\text { Rewards or Prizes } \\
\text { Leaderboards } \\
\text { Badges or Achievements } \\
\text { Virtual Economy } \\
\text { Levels or Progression } \\
\text { Collection and Trading }\end{array}$ & $\begin{array}{l}\text { Social Comparison } \\
\text { Social Competition } \\
\text { Social Discovery } \\
\text { Anonymity } \\
\text { Challenges } \\
\text { Certificates } \\
\text { Quests }\end{array}$ \\
\hline Disruptor & $\begin{array}{l}- \\
- \\
-\end{array}$ & $\begin{array}{l}\text { Innovation Platforms } \\
\text { Voting Mechanisms Development Tools } \\
\text { Creativity Tools }\end{array}$ & $\begin{array}{ll}- & \text { Social Competition } \\
- & \text { Anarchic Gameplay } \\
- & \text { Challenges }\end{array}$ \\
\hline
\end{tabular}

Source: Own study based on Tondello et al., 2016; Marczewski, 2015. 


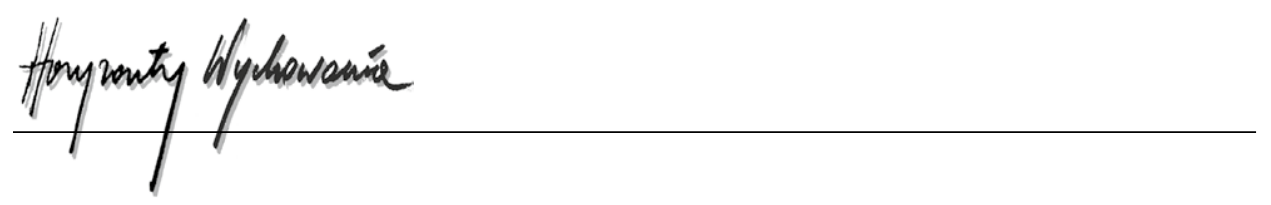

\subsection{Assumption and research hypotheses}

Because of the connection between the effectiveness of gamification and the motivation of participants, personalized campaigns are more effective than those addressed to generally unidentified audience (Tondello, Wehbe, Diamond, Busch, Marczewski, \& Nacke, 2016, pp. 229-243). This statement was an inspiration for research on using elements of game mechanisms to motivate students. Indicated hypotheses result from the conclusions presented earlier in the literature on the subject. The hypotheses were adopted and verified for students of the Cracow University of Economics.

- $\mathrm{H} 1$ : The validity of the use of individual elements of the gamification depends on the target group of participants.

- H2: Player-specific elements do not translate directly into building long-term commitment.

The survey was conducted among students of the Cracow University of Economics. The form contained a standardized test that defined the type of participant of gamification, which consisted of 24 statements displayed in a random order. Respondents determined the agreement on the statement presented in a five-stage scale. The 24 statements correspond to 6 different types of gamification system users (socializer, free spirit, achiever, philanthropist, player and disruptor). Each type is assessed by summing up the values of the participant's response to the four elements that comprise it (Tondello, Mora, \& Marczewski, n.d.).

A. Marczewski's test was chosen for the study, not R. Bartle's, because it is believed that it better determines the actual preferences of users for given game mechanisms. Unlike the test based on R. Bartle's systematics, it does not refer directly to MMORPG activities, but to real-world behavior. This makes the statements understandable even for people who do not know enough about gaming vocabulary. The research took into account the correlation between gamification elements and types of participants as shown in Table 1 in the second section of this paper.

\subsection{Analysis of the results}

The survey was conducted in the form of questionnaires among students between July and December 2019 on a sample of 271 people from 14956 students of the Cracow University of Economics (Universities and their finances 2019). Among the respondents there were both full-time and extramural students, including 153 women and 118 men. Due to other, more specialized questions contained in the research questionnaire, the respondents were recruited from among those who participated in gamification training or in classes with elements of gamification.

The results of the test determining the type of participant are presented in Table 2. 
Table 2

Types of gamification participants among students of the Cracow University of Economics

\begin{tabular}{|l|c|c|}
\hline User types & Size & Percentage \\
\hline Philantropist & 72 & $18 \%$ \\
\hline Socializer & 71 & $18 \%$ \\
\hline Free Spirit & 100 & $25 \%$ \\
\hline Achiever & 67 & $17 \%$ \\
\hline Player & 89 & $22 \%$ \\
\hline Disruptor & 6 & $1 \%$ \\
\hline
\end{tabular}

Source: own study, part of the project „Model projektowania rozwiązań grywalizacyjnych nakierowanych na usprawnianie procesów biznesowych oraz edukacyjnych," Inkubator Innowacyjności 2.0.

Some of the respondents obtained a test result that indicated two types of participants. Therefore the number in the table does not add up to 271 , but reflects the actual share of particular types of participants in the gamification among students of the Cracow University of Economics. The largest number of respondents show motivations consistent with the Free Spirit type (25\%), and the least with Achiever (17\%) and Disruptor (1\%). The same test carried out on a sample of 29,449 people from the general population shows a predominance of people with a motivation appropriate for the philanthropist $(26 \%) .^{2}$

The results of the study allow positive verification of the assumed $\mathrm{H} 1$ hypothesis. According to the concept of gamification personalized to the user types The Cracow University of Economics students are a group for which the distribution of motivators is different from the general public (as studies using the same questionnaire gave different results on a sample from the general population). Therefore, it can be concluded that the gamification should be designed with the target group of participants in mind. According to the relationship between types of users and elements of gamification examined by other researchers, presented in Table 1 in the second section of this paper optimal elements can be distinguished in a system created for UEK students. Translating the results of the study into elements that should include student-dedicated gamification, those are: exploratory tasks, nonlinear gameplay, easter eggs, unlockable content, learning, anonymity, anarchic gameplay seem to be the most important. The additional elements that can be taken into account are; customization, challenges, creativity tools. The analysis of the literature indicated that the majority of people deciding to participate in gameplay are initially guided by external motivation related to the mechanisms characteristics of the player type.

${ }^{2}$ Marczewski's User Types Hexad: http://www.gamified.co.uk/user-types/, as of 19.03 .2020 the database contains 29449 results. 


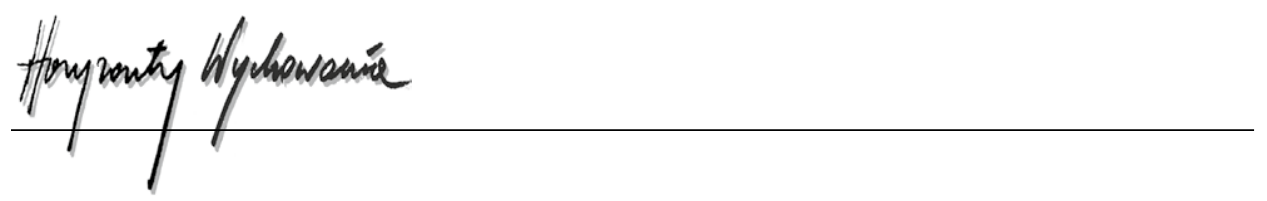

It is worth noting that students demonstrating the player's motivation constitute the second largest set in terms of numbers, which does not allow to unequivocally confirm the $\mathrm{H} 2$ hypothesis that the so-called scoring is not a tool for building long-term commitment. The results of the study indicate that when designing gamification solutions dedicated to students, points, rewards or prizes, leaderboards, badges or achievements, virtual economy, levels or progression, collection and trading should be used. According to the Self-Determination Theory, however, it is indicated that such mechanisms translate into an external or introjective motivation, rather than an internal one, considered to be the most effective.

\section{Conclusions}

The conducted research confirmed the assumed hypothesis that the legitimacy of using particular elements of gamification depends on the target group of participants. The results allow for distinguishing gamification elements appropriate for motivating the Cracow University of Economics students. However, the hypothesis of ineffectiveness of the use of elements specific to the type of player was not confirmed. Further research is needed to verify this assumption, e.g. using a gamification project. Due to the limited research sample, the results do not reflect the entire population, but provide a basis for further research on the motivational elements of individual participants in gamification systems. They can also be treated as a guideline for the implementation of gamification in the curricula addressed to students in Poland.

\section{BIBLIOGRAPHY}

Bartle, R. (1996). Hearts, clubs, diamonds, spades: Players who suit MUDs. Retrieved from: http:// mud.co.uk/richard/hcds.html.

Bogost, I. (2013). Exploitationware. In: R. Colby, M.S.S. Johnson, R.S. Colby (Eds.), Rhetoric/ Composition/Play through Video Games. Palgrave Macmillan, New York: Palgrave Macmillan's Digital Education and Learning.

Burke, B. (2012). Gamification 2020: What Is the Future of Gamification? Gartner, pp. 1-7.

Da Rocha Seixas, L., Gomes, A., \& De Melo Filho, I.J. (2016). Effectiveness of Gamification in the Engagement of Students. Computers in Human Behavior, No. 58, 59.

Deci, E., Vallerand, R., Pelletier, L., \& Ryan, R. (1991). Motivation and Education: The Self-Determination Perspective. Educational Psychologist, 26, 325-346.

Jia, Y., Xu, B., Karanam, Y., \& Voida, S. (2016). Personality-targeted gamification: a survey study on personality traits and motivational affordances. In: Proceedings of the 34th Annual ACM Conference on Human Factors in Computing Systems - CHI '16. https://doi.org/10.1145/2858036.2858515.

Jimenez, S. (n.d.). Gamification Model Canvas. Retrieved from: https://www.gamasutra.com/blogs/ SergioJimenez/20131106/204134/Gamification_Model_Canvas.php (access: 05.03.2020).

Kacprzak-Bieracka, E., Skura-Madziała, A., Kopański, Z., Brukwicka, I., Lishchynsky, Y., \& Mazurek, M. (2014). The concept of motivation, its varieties and subjects of motivation. Journal of Clinical Healthcare, 3, 2-3. 
Kiryakova G., Angelova N., Yordanova L. (2014). Gamification in Education.

Kozłowska, I. (2016). Gamifikacja - specyfika wykorzystania narzędzia w Polsce. Studia Ekonomiczne. Zeszyty Naukowe Uniwersytetu Ekonomicznego w Katowicach, No. 255, 38-40.

Litwin, M. (2014). The notion of gamification in relation to phenomena related to the labour market. Homo Ludens, No. 1.

Marczewski, A. (2015). Even Ninja Monkeys Like to Play: Gamification, Game Thinking and Motivational Design. CreateSpace Independent Publishing Platform.

Mielniczuk, E., Łaguna, M., Januszewski, A., \& Artymiak, M. (2016). Kwestionariusz motywacji do podejmowania szkoleń. Zarządzanie Zasobami Ludzkimi, No. 2, 103-105.

Orji, R., Nacke, L.E., \& Di Marco C. (2017). Towards personality-driven persuasive health games and gamified systems. In: Proceedings of the SIGCHI Conference on Human Factors in Computing Systems - CHI '17. ACM, 1015-1027. https://doi.org/10.1145/3025453.3025577.

Piotrowska, A. \& Puchała, J. (2012). Motivating as a management function within an enterprise. Zarządzanie, notebook 407, Toruń.

Ryan, R. \& Deci, E. (2000). Self-Determination Theory and the Facilitation of Intrinsic Motivation, Social Development, and Well-Being. American Psychologist, Vol. 55, No. 1, 68-73.

Sahin, C. \& Namli, A. (2016, January). Gamification and effects on students' science lesson achievement. International Journal on New Trends in Education and Their Implications Volume: 7 , Issue: $1,41$.

Swacha, J. (2015). Gamification of e-learning in the context of different types of participants. Zeszyty Naukowe Uniwersytetu Szczecińskiego Studia Informatica, No. 38, 180.

Tondello, G.F., Mora, A., Marczewski, A., \& Nacke, E.L. (n.d.). D'empirical validation of the Gamification User Types Hexad scale in English and Spanish. International Journal of Human-Computer Studies.

Tondello, G.F., Wehbe, R.R., Diamond, L., Busch, M., Marczewski, M., \& Nacke, L.E. (2016). The gamification user types Hexad scale. In: Proceedings of the 2016 Annual Symposium on Computer-Human Interaction in Play - CHI PLAY'16. Austin, TX, USA. ACM, 229-243. https:// doi.org/10.1145/2967934.2968082.

Universities and their finances in 2018 (2019). Retrieved from: https://stat.gov.pl/.

Werbach, K. \& Hunter, D. (2012). For the win. How game thinking can revolutionize your business. Philadelphia: Wharton, pp. 72.

Zainuddina, Z., Kai Wah Chua, S., Shujahata, M., \& Jacqueline Perera, C. (2020). The impact of gamification on learning and instruction: A systematic review of empirical evidence. Educational Research Review, Vol. 30. https://doi.org/10.1016/j.edurev.2020.100326

Zając, M. (2014). Gra w edukację i profile graczy. Retrieved from: http://www.e-mentor.edu.pl/blog/ wpis/id/72.

Zicherman, G., \& Cunningham, C. (2011). Gamification by design, Implementing Game Mechanism in Web and Mobile Apps. Sebastopol: O'Reilly, 35-36.

\section{Copyright and License}

This article is published under the terms of the Creative Commons Attribution - NoDerivs (CC BY- ND 4.0) License http://creativecommons.org/licenses/by-nd/4.0/ 